\title{
Kemampuan Aktinomiset Menghambat Pertumbuhan Sclerotium rolfsii dan Pembiakannya pada Medium Serbuk Gergaji
}

\section{Ability of Actinomycetes to Suppress the Growth of Sclerotium rolfsii and Use of Sawdust as Its Culture Medium}

\author{
Nurul Widyanti, Giyanto* \\ Institut Pertanian Bogor, Bogor 16680
}

\begin{abstract}
ABSTRAK
Aktinomiset merupakan salah satu mikroorganisme yang dapat digunakan sebagai agens hayati. Pembiakan aktinomiset secara massal untuk aplikasinya di lapangan mengalami kendala terutama dari segi biaya yang tinggi, oleh karena itu dibutuhkan medium alternatif yang murah dan mudah didapat sebagai medium pertumbuhan aktinomiset. Tujuan penelitian ialah memiliki isolat aktinomiset untuk menekan pertumbuhan Sclerotium rolfsii serta menganalisis pertumbuhannya dalam medium tumbuh berbahan dasar limbah organik serbuk gergaji dan dedak. Biakan aktinomiset APS 7, APS 9, APS 12, dan ATS 5 diuji secara in vitro terhadap $S$. rolfsii. Hasil penelitian menunjukkan hanya isolat APS 7 yang memiliki potensi sebagai agens hayati terhadap $S$. rolfsii dengan nilai penghambatan sebesar $91.73 \%$ pada inkubasi minggu ketiga. Secara umum baik medium serbuk gergaji maupun medium dedak memiliki potensi dijadikan medium tumbuh aktinomiset APS 7. Setelah 8 minggu periode inkubasi rata-rata populasi aktinomiset yang tumbuh pada medium yang mengandung serbuk gergaji atau dedak berturut-turut $335 \times 10^{6} \mathrm{cfu} / \mathrm{g}$ dan $331 \times 10^{6} \mathrm{cfu} / \mathrm{g}$.
\end{abstract}

Kata kunci: agens hayati, dedak, limbah organik padat

\begin{abstract}
Antagonistics microorganisms, such as actinomycetes, are potential biological control agents for plant diseases. Mass culture of actinomycetes to provide enough inoculum for field application is sometimes costly. Therefore alternative medium with simple preparation and relatively less costly is required for mass culture of actinomycetes. This research was conducted to evaluate the ability of 4 actinomycetes isolates, i.e. APS 7, APS 9, APS 12, and ATS 5, in suppressing growth of Sclerotium rolfsii in vitro and to assess the growth of actinomycetes in alternatif medium containing organic wastes, i.e sawdust and bran. Among 4 tested isolates of actinomycetes only APS 7 showed its potency as biocontrol agents for S. rolfsii with growth suppression rate of $91.73 \%$ after 3 weeks incubation. In general, both sawdust and bran has the potency as culture medium for APS 7. After 8 weeks incubation period the average population of actinomycetes grew in culture medium containing sawdust and bran was $335 \times 10^{6} \mathrm{cfu} / \mathrm{g}$ and $331 \times 10^{6} \mathrm{cfu} / \mathrm{g}$, respectively.
\end{abstract}

Key words: biocontrol agents, bran, organic waste

\footnotetext{
*Alamat penulis korespondensi: Departemen Proteksi Tanaman, Fakultas Pertanian, Institut Pertanian Bogor, Kampus Darmaga, Jalan Kamper, Bogor 16680

Tel: 0251-8629364, Faks: 0251-8629362, Surel: giyanto2@yahoo.com
} 


\section{PENDAHULUAN}

Sclerotium rolfsii merupakan patogen yang memiliki kisaran inang luas di antaranya, bawang merah, kacang hijau, kacang tanah, kubis, timun dan tomat. Tanaman inang yang terinfeksi akan mengalami rebah kecambah, busuk pangkal batang, dan busuk akar sehingga proses fisiologi tanaman terganggu. Pada tanaman dewasa gejala yang ditimbulkan berupa bercak kuning hingga kemerahan pada pangkal batang dan menghasilkan sklerotium yang mampu bertahan hidup di dalam tanah. Pengendalian $S$. rolfsii yang sudah banyak dilakukan meliputi upaya memusnahkan inokulum cendawan seperti pembuangan sisa tanaman, solarisasi, rotasi tanaman, dan penggunaan fungisida.

Pengendalian menggunakan fungisida berbahan dasar mikroorganisme telah banyak digunakan, diantaranya ialah aktinomiset. Aktinomiset memegang peranan penting dalam memacu pertumbuhan tanaman baik secara langsung maupun tidak langsung. Secara langsung dilakukan dengan menghasilkan fitohormon, melarutkan fosfat, dan meningkatkan kemampuan menyerap nutrisi; sedangkan secara tidak langsung dengan mengendalikan patogen (kompetisi, parasitisme, produksi metabolit sekunder) dan menginduksi ketahanan tanaman (Barreto et al. 2008). Uji aktinomiset telah dilakukan pada biji, bibit, dan medium tanam untuk menekan perkembangan patogen rebah kecambah dan patogen tular tanah lainnya (Lahdenpera 2000). Streptomyces sp. mampu menghambat pertumbuhan patogen Ralstonia solanacearum pada tanaman pangan (Akhdiya dan Susilowati 2008), S. rolfsii pada buncis (Reddy 2010), dan Xanthomonas oryzae pv.oryzae pada padi (Putra 2011).

Pembiakan aktinomiset secara massal membutuhkan biaya produksi yang tinggi karena medium pembiakan aktinomiset cukup mahal harganya. Medium tumbuh alternatif agens hayati dalam bentuk formulasi dengan bahan dasar limbah organik telah banyak diteliti dan diproduksi secara massal. Ratdiana (2007) dan Rismawan (2011) membuat formulasi medium berasal dari limbah organik cair dan limbah cair ternak sebagai medium untuk Pseudomonas fluorescens.

Nonomura dan Ohara (1969) menjelaskan bahwa banyak aktinomiset hidup sebagai saprob dan aktif mendekomposisi bahan organik di dalam tanah. Jumlah aktinomiset dalam tanah ditentukan oleh ketersediaan bahan organik segar dan $\mathrm{pH}$ tanah. Berdasarkan ketersediaan limbah organik berupa sisa serutan kayu dan limbah penggilingan padi maka dibuatlah suatu gagasan untuk menjadikan limbah organik tersebut sebagai medium pembiakan aktinomiset. Penelitian ini bertujuan mengevaluasi kemampuan isolat aktinomiset dalam menekan pertumbuhan S. rolfsii serta menentukan pertumbuhannya pada medium berbahan dasar limbah organik serbuk gergaji dan dedak.

\section{BAHAN DAN METODE}

\section{Perbanyakan Aktinomiset dan $\boldsymbol{S}$. rolfsii}

Isolat aktinomiset APS 7, APS 9, dan APS 12 berasal dari Laboratorium Bakteriologi Tumbuhan, Departemen Proteksi Tanaman, Institut Pertanian Bogor, dan isolat aktinomiset ATS 5 berasal dari tanah persawahan di daerah Cikarawang (Himmah 2012). Isolat murni diperbanyak menggunakan medium agar-agar water yeast extract (WYE) (0.25 g ekstrak khamir, $0.5 \mathrm{~g} \mathrm{~K}_{2} \mathrm{HPO}_{4}, 18 \mathrm{~g}$ agar-agar, dan $1 \mathrm{~L}$ akuades) (Crawford et al. 1993) dan diinkubasi pada suhu ruang $28{ }^{\circ} \mathrm{C}$ selama $7-14$ hari. Isolat $S$. rolfsii diremajakan pada medium potato dextrose agar (PDA) lalu diinkubasi pada suhu ruang $28^{\circ} \mathrm{C}$ selama 7 hari.

\section{Uji in Vitro Penghambatan S. rolfsii oleh Aktinomiset}

Uji antagonis aktinomiset dilakukan menggunakan metode peracunan medium tumbuh (medium poissoning) S. rolfsii. Medium yang digunakan ialah PDA. Sebanyak satu ose aktinomiset berumur 14 hari diinokulasikan 
ke dalam $15 \mathrm{~mL}$ medium WYE cair dan diinkubasi pada inkubator bergoyang dengan kecepatan $100 \mathrm{rpm}$ selama 7, 14, 21, dan 28 hari. WYE cair yang mengandung biakan aktinomiset, masing-masing sebanyak $1 \mathrm{~mL}$ dimasukkan ke dalam tabung eppendorf dan disentrifugasi dengan kecepatan $12000 \mathrm{rpm}$ selama 10 menit untuk mendapatkan supernatan yang mengandung senyawa bioaktif aktinomiset.

Supernatan dimasukkan ke dalam labu erlenmeyer steril $200 \mathrm{~mL}$ dan dipanaskan pada inkubator pada $65{ }^{\circ} \mathrm{C}$ selama 30 menit. Supernatan selanjutnya didiamkan pada suhu ruang selama 60 menit dan dipanaskan kembali selama 30 menit pada suhu yang sama supaya sel vegetatif aktinomiset mati. Penyiapan supernatan dengan sentrifugasi dan pemanasan dilakukan untuk memastikan bahwa supernatan yang dihasilkan bebas sel aktinomiset yang dibuktikan dengan uji pencawanan pada medium tumbuh. Cairan yang mengandung senyawa bioaktif dicampurkan ke dalam medium PDA cair $\left(50{ }^{\circ} \mathrm{C}\right)$. Medium ini dituang ke dalam cawan petri (diameter $9 \mathrm{~cm}$ ), selanjutnya diinokulasikan $S$. rolfsii yang berumur 7 hari dan diinkubasi pada suhu ruang $28^{\circ} \mathrm{C}$ selama 3 hari. Percobaan diulang sebanyak dua kali.

Penghambatan pertumbuhan $S$. rolfsii dihitung dengan persamaan:

Daya hambat $=\frac{\text { DK-DP }}{\text { DK }} \times 100 \%$, dengan

DK, diameter koloni S. rolfsii pada kontrol; DP, diameter koloni $S$. rolfsii pada perlakuan. Aktinomiset yang memiliki keefektifan tertinggi dalam menekan pertumbuhan $S$. rolfsii diuji lanjut.

\section{Pertumbuhan Aktinomiset pada Medium Limbah Organik}

Serbuk gergaji kayu kihiyang (Albizzia procerra) dan dedak kering digunakan sebagai bahan utama dalam medium tumbuh (Tabel 1).

Bahan-bahan pembuatan medium limbah organik dicampurkan hingga kondisi homogen dengan penambahan air sehingga campuran bahan dapat menggumpal, tetapi tidak sampai meneteskan air. Derajat keasaman medium diukur menggunakan kertas lakmus dengan nilai antara 6.5 dan 8. Sebanyak $200 \mathrm{~g}$ bahan dimasukkan ke dalam plastik polipropilen $1 \mathrm{~kg}$ tahan panas. Ujung plastik diberi cincin pipa (diameter $4 \mathrm{~cm}$ ), disumbat kapas dan ditutup dengan kertas putih, kemudian medium tumbuh ini disterilkan pada suhu $120^{\circ} \mathrm{C}$ selama 15 menit. Medium tumbuh steril disimpan pada suhu $28^{\circ} \mathrm{C}$ selama 24 jam sebelum diinokulasi dengan biakan aktinomiset.

Pembiakan aktinomiset dilakukan dengan mencampurkan $10 \mathrm{~mL}$ air steril ke dalam biakan aktinomiset (berumur 14 hari), kemudian spora dipanen menggunakan spatula steril hingga tersuspensi. Suspensi spora yang telah tercampur diambil sebanyak $1.25 \mathrm{~mL}$ (1 g medium terdapat koloni aktinomiset dengan kerapatan $1 \times 10^{3} \mathrm{cfu} / \mathrm{mL}$ ) lalu disuspensikan ke dalam $8.75 \mathrm{~mL}$ air steril hingga total menjadi $10 \mathrm{~mL}$. Suspensi sebanyak $10 \mathrm{~mL}$ dimasukkan ke dalam $200 \mathrm{~g}$ medium limbah organik, kemudian suspensi dihomogenkan bersamaan dengan medium. Semua proses inokulasi aktinomiset ke dalam medium dilakukan secara aseptik. Medium diinkubasi selama 0, 2, 4, 6, dan 8 minggu pada suhu ruang $\left(28{ }^{\circ} \mathrm{C}\right)$. Pengulangan dilakukan sebanyak lima kali.

Tabel 1 Komposisi medium serbuk gergaji dan dedak untuk perbanyakan aktinomiset

\begin{tabular}{lcc}
\hline Bahan & Serbuk gergaji $(\mathrm{g})$ & Dedak $(\mathrm{g})$ \\
\hline Serbuk gergaji & 90.0 & 0.0 \\
Dedak & 0.0 & 90.0 \\
Ampas tahu & 88.6 & 77.0 \\
Kapur pertanian & 5.4 & 17.0 \\
Glukosa & 10.0 & 10.0 \\
Susu skim & 5.0 & 5.0 \\
Tepung limbah udang & 1.0 & 1.0 \\
\hline
\end{tabular}




\section{Penghitungan Populasi Aktinomiset pada Medium Limbah Organik}

Penghitungan populasi aktinomiset dilakukan dengan metode pengenceran berkala $\left(10^{0}, 10^{-1}, 10^{-2}, 10^{-3}, 10^{-4}\right.$, dan $\left.10^{-5}\right)$ pada medium tumbuh yang telah diinkubasi selama $0,2,4,6$, dan 8 minggu. Setiap pengenceran $10^{-3}, 10^{-4}$, dan $10^{-5}$ diambil masing-masing sebanyak $0.1 \mathrm{~mL}$ untuk disebar secara merata pada medium agar-agar WYE. Aktinomiset diinkubasi selama 3-7 hari untuk menghitung populasi koloninya. Indikator adanya koloni aktinomiset ialah terdapat koloni tunggal berukuran 1-10 mm yang memiliki filamen berdebu seperti miselium dan berbau khas tanah. Data diambil berdasarkan pada penghitungan koloni yang terdapat pada medium agar-agar WYE, koloni dihitung menggunakan metode plate count. Populasi aktinomiset APS 7 pada medium limbah organik dihitung dengan persamaan:

Populasi bakteri $=\frac{\mathrm{X}_{\mathrm{i}} \times \mathrm{V}}{\mathrm{pi} \times \mathrm{r} \times \mathrm{g}}$, dengan

$\mathrm{Xi}$, rataan koloni aktinomiset dengan faktor pengenceran ke-i (cfu/mL); V, volume pengenceran medium (mL); pi, faktor pengenceran ke-i; r, volume suspensi yang disebar pada cawan $(\mathrm{mL})$; g, bobot medium yang digunakan.

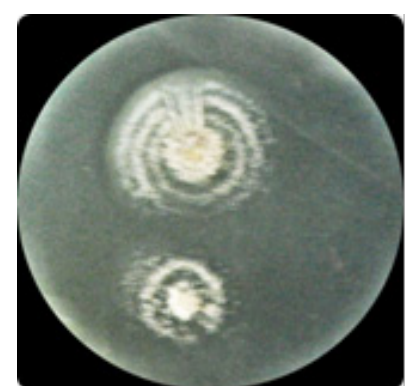

a

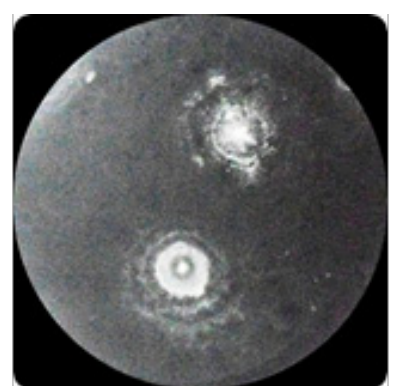

b

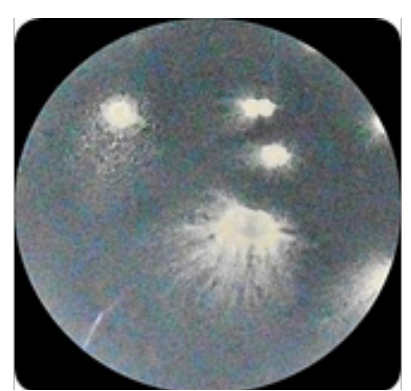

c

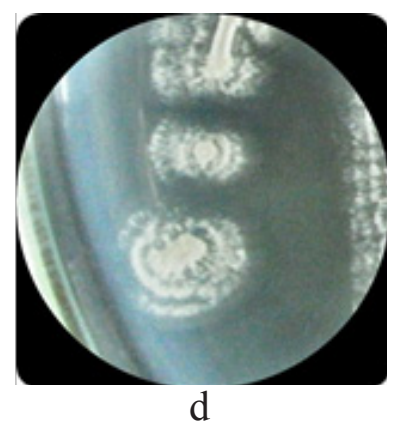

Gambar 1 Koloni aktinomiset pada medium agar-agar WYE. a, Isolat APS 7 memiliki koloni dengan bentuk sirkuler tak penuh dan berwarna cokelat kekuningan dengan hifa aerial yang menutupi permukaan koloni; b, Isolat APS 9 memiliki koloni dengan bentuk sirkuler penuh dan berwarna putih dengan hifa aerial yang tidak menutupi permukaan koloni; c, Isolat APS 12 memiliki koloni dengan hifa aerial menyebar teratur ke segala arah dan berwarna cokelat; dan d, Isolat ATS 5 memiliki koloni dengan bentuk pipih memanjang dan berwarna abu-abu dengan hifa aerial yang menutupi permukaan koloni. 
Uji in Vitro Penghambatan S. rolfsii oleh Aktinomiset

Pengaruh senyawa bioaktif aktinomiset terhadap pertumbuhan miselium cendawan $S$. rolfsii menunjukkan hasil yang bervariasi jika dibandingkan dengan kontrol (Gambar 2). Kemampuan daya hambat isolat aktinomiset terhadap pertumbuhan miselium cendawan $S$. rolfsii merupakan suatu akibat adanya aktivitas antimikrob yang dimiliki oleh aktinomiset

Di antara keempat isolat aktinomiset yang digunakan untuk uji antagonis terhadap cendawan, isolat APS 7 memiliki daya hambat tertinggi pada pertumbuhan $S$. rolfsii selama 4 minggu waktu inkubasi (Tabel 2). Pada inkubasi minggu pertama, daya hambat isolat APS 7, APS 9, APS 12, dan ATS 5 berturutturut $46.42 \%, 21.42 \%, 17.50 \%$, dan $1.75 \%$. Pada inkubasi minggu ke-2 semua isolat yang digunakan mengalami peningkatan kemampuan daya hambat dengan daya hambat tertinggi tetap pada isolat APS 7 $(74.02 \%)$ dan terendah pada isolat ATS 5 (38.98\%). Pada inkubasi minggu ke-3 daya hambat oleh isolat APS 7 (91.73\%) dan ATS 5
(64.06\%) mengalami peningkatan, tetapi APS $9(26.04 \%)$ dan APS 12 (23.88\%) mengalami penurunan. Pada inkubasi minggu ke-4 daya hambat oleh isolat APS 9 (35.50\%) dan APS $12(69.50 \%)$ mengalami peningkatan, tetapi APS 7 (79.87\%) dan ATS 5 (56.12\%) mengalami penurunan.

\section{Penghitungan Populasi Aktinomiset pada Medium Limbah Organik}

Pembiakan aktinomiset APS 7 pada medium tumbuh serbuk gergaji dan dedak menunjukkan adanya kondisi yang fluktuatif pada jumlah populasi (Gambar 3). Berdasarkan pada penghitungan yang telah dilakukan dapat diketahui bahwa terdapat perbedaan jumlah populasi aktinomiset APS 7 pada setiap minggunya. Pertumbuhan aktinomiset pada medium serbuk gergaji dan dedak memiliki nilai yang tidak berbeda nyata. Dengan demikian dapat disimpulkan bahwa medium serbuk gergaji dan medium dedak memiliki potensi yang sama sebagai medium pembiakan aktinomiset. Medium serbuk gergaji memiliki nilai log populasi aktinomiset

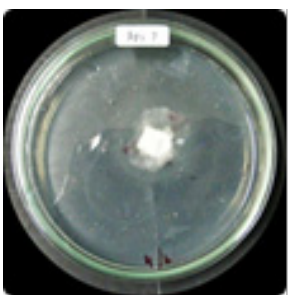

a

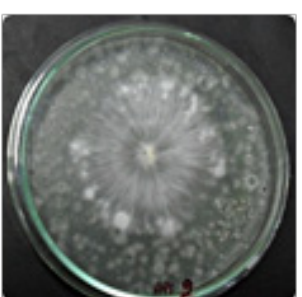

b

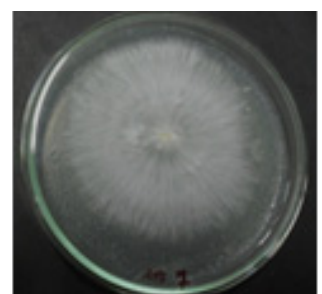

c

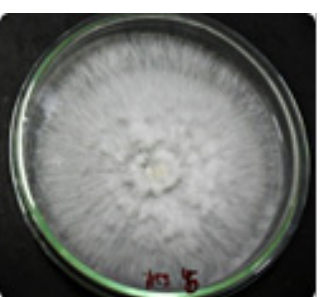

d

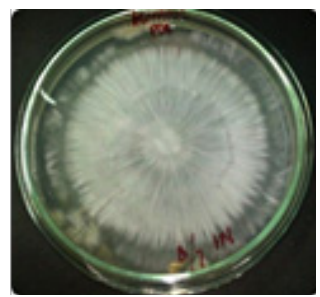

e

Gambar 2 Variasi aktivitas penghambatan pertumbuhan miselium Sclerotium rolfsii pada senyawa bioaktif aktinomiset. a, APS 7; b, APS 9; c, APS 12; d, ATS 5; e, Kontrol (tidak diberi larutan senyawa bioaktif aktinomiset).

Tabel 2 Penghambatan pertumbuhan Sclerotium rolfsii oleh beberapa isolat aktinomiset selama 4 minggu masa inkubasi

\begin{tabular}{lrccr}
\hline Perlakuan & \multicolumn{4}{c}{ Daya hambat $(\%) *$ pada minggu ke- } \\
\cline { 2 - 5 } (isolat aktinomiset) & \multicolumn{1}{c}{ 1 } & \multicolumn{1}{c}{. } & \multicolumn{1}{c}{4} \\
\hline Kontrol & 0.00 & 0.00 & 0.00 & 0.00 \\
APS 7 & 46.42 & 74.02 & 91.73 & 79.87 \\
APS 9 & 21.42 & 41.96 & 26.04 & 35.50 \\
APS 12 & 17.50 & 38.98 & 23.88 & 69.50 \\
ATS 5 & 1.75 & 18.97 & 64.06 & 56.12 \\
\hline
\end{tabular}

*Rata-rata dari dua ulangan yang diukur pada hari ke-3 setelah masa inkubasi. 


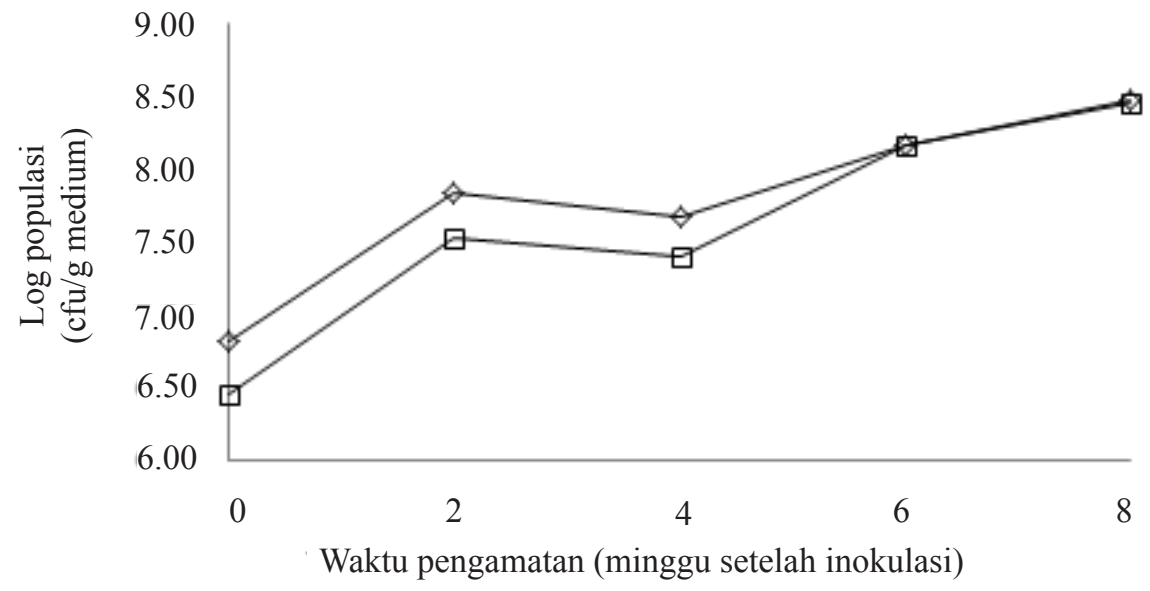

Gambar 3 Perkembangan populasi aktinomiset APS 7 pada medium serbuk gergaji $(-\bullet)$ dan dedak ( $\square$ ) dengan masa inkubasi 0-8 minggu.

sebesar $6.81\left(7.9 \times 10^{6} \mathrm{cfu} / \mathrm{g}\right.$ medium $)$ pada inkubasi minggu ke-0. Peningkatan populasi terjadi pada inkubasi minggu ke-2 dengan nilai sebesar 7.84 (71.5 x $10^{6} \mathrm{cfu} / \mathrm{g}$ medium). Pada inkubasi minggu ke-4, terjadi penurunan nilai $\log$ populasi sebesar $7.68\left(50.2 \times 10^{6} \mathrm{cfu} / \mathrm{g}\right.$ medium), tetapi populasi kembali meningkat pada inkubasi minggu ke- 6 dan ke-8, berturutturut sebesar $8.16\left(148 \times 10^{6} \mathrm{cfu} / \mathrm{g}\right.$ medium $)$ dan 8.48 (335 x $10^{6} \mathrm{cfu} / \mathrm{g}$ medium).

Keadaan yang sama terjadi pada medium dedak dengan nilai log populasi awal sebesar 6.44 (3.16 x $10^{6} \mathrm{cfu} / \mathrm{g}$ medium) diikuti dengan terjadinya peningkatan pada minggu ke-2 sebesar 7.52 (34.75 x $10^{6} \mathrm{cfu} / \mathrm{g}$ medium). Penurunan populasi terjadi pada inkubasi minggu ke-4 sebesar $7.40\left(28.80 \times 10^{6} \mathrm{cfu} / \mathrm{g}\right.$ medium) tetapi kemudian nilai populasi terus meningkat pada minggu ke- 6 dan ke- 8 dengan nilai berturut-turut $8.16\left(143.5 \times 10^{6} \mathrm{cfu} / \mathrm{g}\right.$ medium), dan 8.45 (331 x $10^{6} \mathrm{cfu} / \mathrm{g}$ medium).

\section{PEMBAHASAN}

Beberapa penelitian terdahulu membuktikan bahwa aktinomiset mampu menghambat pertumbuhan berbagai jenis patogen. Isolat Streptomyces sp. dibuktikan mampu menekan pertumbuhan Pythium ultimum pada tanaman selada (Crawford et al. 1993) dan Streptomyces nigrifaciens mampu menghambat pertumbuhan $S$. rolfsii pada tanaman buncis (Reddy 2010). Aktinomiset merupakan mikroorganisme yang mampu menyintesis banyak senyawa bioaktif berupa metabolit sekunder, antibiotik, pestisida, antiseptik, selulase, dan xylanase (Oskay et al. 2004). Aktinomiset juga mampu menghasilkan senyawa antimikrob seperti tertasiklin, streptomisin, eritromisin, kloramfenikol, ivermektin, dan rifampisin (Todar 2008). Pertumbuhan aktinomiset pada medium biakan tampak mengalami dinamika.

Populasi aktinomiset dapat meningkat karena tersedianya nutrisi pada medium biakan, sedangkan menurunnya populasi aktinomiset diduga karena pengurangan aktivitas yang disebabkan oleh adaptasi awal pemindahan biakan ke medium biakan baru (medium limbah organik), berkurangnya sumber hara esensial dan terbentuknya senyawa penghambat pertumbuhan. Hasil penghitungan populasi dan rata-rata koloni aktinomiset pada masing-masing medium uji menunjukkan bahwa aktinomiset mampu beradaptasi dengan baik terhadap medium yang terdiri atas beberapa komponen limbah organik. Perpaduan limbah serbuk gergaji/ dedak, ampas tahu, tepung limbah udang serta penambahan bahan penunjang lainnya terbukti dapat mendukung pertumbuhan aktinomiset. Bahan penunjang yang digunakan untuk membuat medium seperti glukosa, susu skim dan tepung limbah udang memiliki komposisi jumlah bahan yang sama pada setiap medium uji, kecuali jumlah ampas tahu dan kapur 
pertanian. Pada medium serbuk gergaji terdapat $44.3 \%$ ampas tahu dan $2.7 \%$ kapur, sedangkan pada medium dedak hanya terdapat 38.5\% ampas tahu dan $8.5 \%$ kapur.

Kandungan nutrisi dan mineral yang terdapat di dalam $100 \mathrm{~g}$ serbuk gergaji, yaitu $35.3 \mathrm{~g}$ serat kasar, $31.0 \mathrm{~g}$ selulosa, $30.9 \mathrm{~g}$ lignin, $0.9 \mathrm{~g}$ protein kasar, dan $1.9 \mathrm{~g}$ lemak kasar. Berdasarkan pada kandungan nutrisi yang terdapat di dalam serbuk gergaji, medium ini dapat dijadikan bahan utama sumber karbon, fosfor, dan kalium yang telah tersedia dalam jaringan kayu. Sesuai dengan karakteristik aktinomiset yang mampu mendegradasi selulosa dan lignin di samping kapang dan khamir (Xu et al. 1996) maka serbuk gergaji dapat dijadikan medium tumbuh karena kandungan selulosa dan lignin yang tinggi.

Kandungan nutrisi dan mineral yang terdapat dalam $100 \mathrm{~g}$ ampas tahu, yaitu $17.4 \mathrm{~g}$ karbohidrat, $67.5 \mathrm{~g}$ protein, $10.6 \mathrm{~g}$ lemak, dan $4.499 \mathrm{~g}$ mineral (Sulistiani 2004). Adanya kandungan protein yang cukup tinggi tersebut dapat dimanfaatkan untuk pertumbuhan aktinomiset karena bila kekurangan protein atau salah satu asam amino esensial akan mengakibatkan penurunan pertumbuhan secara menyeluruh sesuai dengan derajat kekurangannya.

Pembiakan aktinomiset pada medium dedak didasarkan pada kandungan nutrisi yang terdapat di dalamnya. Dalam $100 \mathrm{~g}$ dedak mengandung $70 \mathrm{~g}$ karbohidrat, $12 \mathrm{~g}$ lemak, dan $16 \mathrm{~g}$ protein serta terdapat $200 \mathrm{mg}$ vitamin B15 (Blair 2008). Medium ini menyumbang banyak karbohidrat untuk pertumbuhan aktinomiset dilihat dari jumlah kandungan karbohidrat dalam $100 \mathrm{~g}$ dedak. Pemberian kapur pada medium berfungsi untuk mengontrol $\mathrm{pH}$, selain itu kapur juga mengandung kalsium, kandungan kalsium dibutuhkan untuk pertumbuhan aktinomiset. Jumlah kapur pada medium dedak yang tinggi menandakan bahwa medium ini memiliki tingkat derajat keasaman yang tinggi pula. Aktinomiset dapat tumbuh pada $\mathrm{pH}$ 6.5-8.0, hal ini menunjukkan bahwa mikrob ini hanya dapat hidup pada lingkungan yang memiliki $\mathrm{pH}$ netral sampai sedikit basa.

Penampakan medium dedak setiap minggunya memiliki tingkat kebasahan yang lebih tinggi daripada medium serbuk gergaji. Hal ini didasarkan pada karakteristik dedak yang higroskopi, diperkuat dengan ditambahnya ampas tahu pada medium dedak menjadikan medium ini selalu dalam keadaaan basah atau tidak kering. Aktinomiset relatif menyukai kondisi lingkungan yang kering atau sedikit air (Hasegawa et al. 2005). Medium serbuk gergaji memiliki kondisi yang selalu kering, sesuai dengan komponen yang terdapat di dalamnya berupa serat kasar dari kayu yang memiliki daya serap yang tinggi terhadap air.

Secara umum dapat disimpulkan bahwa baik medium serbuk gergaji maupun medium dedak memiliki potensi sebagai medium tumbuh aktinomiset dan hanya isolat APS 7 yang memiliki potensi sebagai agens pengendalian hayati terhadap S. rolfsii. Perlu dilakukan penelitian lanjut untuk pengujian keefektifan isolat APS 7 menghambat pertumbuhan $S$. rolfsii pada tahap in vivo, pembiakan aktinomiset pada medium tumbuh limbah organik dengan aplikasi di lapangan, dan mengevaluasi daya simpannya dalam jangka waktu tertentu.

\section{DAFTAR PUSTAKA}

Akhdiya A, Susilowati DN. 2008. Aktivitas penghambatan bakteriosin dari aktinomiset terhadap bakteri patogen dan patogen tular makanan. Jurnal Tanaman Pangan. 27(1):55-60.

Barreto TR, Silva AC, Soares, Souza JT. 2008. Population densities and genetic diversity of actinomycetes associated to the rhizosphere of Theobroma cacao. Braz J Microbiol. 39(3):464-470. DOI: http://dx.doi.org/10.1590/S 1517 83822008000300010.

Blair R. 2008. Nutrition and Feeding of Organic Poultry. Pondicherry (IN): Cromwell Press. DOI: http://dx.doi.org/10.1079/978184593 4064.0000.

Crawford DL, James ML, John MW, Margaret AO. 1993. Isolation and characterization of actinomycete antagonis of a fungal root pathogen. Appl Environ Microbiol. 59(11):3899-3905. 
Hasegawa S, Akane M, Kazuiro T, Tomio N, Hitoshi K. 2005. Drought tolerance of tissue cultured seedlings of mountain Laurel (Kalmia latifolia L.) induced by an endophitic actinomycete. Actinomycetologica. 19(1):13-17. DOI: http://dx.doi.org/10.3209/saj.19.13.

Himmah NF. 2012. Seleksi dan indentifikasi aktinomiset sebagai agens hayati untuk pengendalian penyakit kresek yang diakibatkan oleh Xanthomonas oryzae pv. oryzae pada padi [skripsi]. Bogor (ID): Institut Pertanian Bogor.

Lahdenpera ML. 2000. How mycostop acts in the control of fungal plant diseases. Infoletter Verdera. 5:1-2.

Nonomura H, Ohara Y. 1969. Distribution of soil actinomycetes-culture method effective for both preferential isolation and enumeration of Microbispora and Streptosporangium strains in soil. J Ferment Technol. 47:463-469.

Oskay MO, Tamer U, Azeri C. 2004. Antibacterial activity of some actinomycetes isolated from farming soils of Turkey. Afr J Biotechnol. 3(9):441-446.

Putra MC. 2011. Kompatibilitas Bacillus spp. dan aktinomiset sebagai agens hayati Xanthomonas oryzae pv. oryzae dan pemicu pertumbuhan padi [skripsi]. Bogor (ID): Institut Pertanian Bogor.
Ratdiana. 2007. Kajian pemanfaatan air kelapa dan limbah cair peternakan sebagai medium alternatif perbanyakan Pseudomonas fluorescens serta uji potensi antagonismenya terhadap Ralstonia rolfsii [skripsi]. Bogor (ID): Intitut Pertanian Bogor.

Reddy PP. 2010. Fungal Disease and their Managemant in Horticultural Crops. New Delhi (IN): Scientific Publishers Journals Dept.

Rismawan AK. 2011. Keefektifan formulasi Pseudomonas fluorescens dalam limbah organik sebagai pestisida hayati dan pemicu pertumbuhan tanaman cabai [skripsi]. Bogor (ID): Institut Pertanian Bogor.

Sulistiani. 2004. Pemanfaatan ampas tahu sebagai alternatif bahan baku pangan fungsional [skripsi]. Bogor (ID): Institut Pertanian Bogor.

Todar K. 2008. Antimicrobial Agents Used in Treatment of Infection Disease [research report]. Madison (US): University of Wisconsin.

Xu LH, QR Li, CL Jiang. 1996. Diversity of soil actinomycetes in Yunnan, China. Appl Environ Microbiol. 62(1):244-248. 